\title{
The farmer empowerment to reduce the chemical risk poisoning through liquid organic fertilizers usage
}

\author{
Charloq $^{1}$, Eka Lestari Mahyuni ${ }^{2 *}$ \\ ${ }^{1}$ Departemen Agroekoteknologi, Fakultas Pertanian, Universitas Sumatera Utara \\ ${ }^{2}$ Departemen Keselamatan dan Kesehatan Kerja, Fakultas Kesehatan Masyarakat, Universitas \\ Sumatera Utara \\ *Email: eka.lestari@usu.ac.id
}

\begin{abstract}
The high frequency of chemicals use such as fertilizers and pesticides in intercropping planting patterns giving farmers a high risk of poisoning exposure. This devotion applies the appropriate technology in organic ponds to produce Liquid Organic Fertilizer (POC). The use of POC is horticultural farmers empowered which is useful for improving poor organic soil conditions and producing organic products with the object of chili and vegetable crops. POC applied to soil and plants can increase agricultural growth and production, thus providing a strong basis for farmers to reduce chemical use. The results of the treatment were observed through plant growth and production, accompanied by intensive assistance, as innovations applied in this PPM activity. The resulting output is the effectiveness of POC which is applied to chili and vegetable crops. Empowerment activities show a significant development in which soil conditions become more fertile, leaf thickness increases and becomes greener, plant stems are stronger, pest and disease attacks can be suppressed. This community dedication is very beneficial for the farming community and helps in creating healthy farmers and the environment.
\end{abstract}

Keyword: organic ponds, pesticides, health farmers, POC, chemical fertilizers

\begin{abstract}
Abstrak
Penggunaan bahan kimia seperti pupuk dan pestisida yang banyak dengan frekuensi yang tinggi pada pola penanaman tumpang sari membuat petani berisiko tinggi terpapar keracunan bahan kimia. Kegiatan pengabdian ini menerapkan teknologi tepat guna berupa pembuatan kolam organik untuk menghasilkan Pupuk Organik Cair (POC). Pemanfaatan POC diberdayakan pada petani hortikultura yang berguna untuk memperbaiki kondisi tanah yang miskin organik dan menghasilkan produk organik dengan objek tanaman cabai dan sayuran. POC yang diaplikasi pada tanah dan tanaman dapat meningkatkan pertumbuhan dan produksi pertanian sehingga menjadi dasar yang kuat bagi petani untuk mengurangi penggunaan bahan kimia. Hasil perlakuan tersebut diobservasi melalui pertumbuhan dan produksi tanaman disertai pendampingan yang intensif menjadi metode penerapan dari inovasi yang diterapkan dalam kegiatan PPM ini. Luaran yang dihasilkan berupa efektifitas POC yang diterapkan pada tanaman cabai dan sayuran. Kegiatan pemberdayaan menunjukkan perkembangan yang signifikan karena kondisi tanah menjadi lebih subur, meningkatnya tebal daun dan menjadi lebih hijau, batang tanaman lebih kokoh, serangan hama, dan penyakit dapat ditekan. Kegiatan pengabdian ini sangat bermanfaat bagi masyarakat petani dan membantu dalam menciptakan petani dan lingkungan yang sehat.
\end{abstract}

Kata Kunci: kolam organik, pestisida, petani sehat, POC, pupuk kimia

\section{PENDAHULUAN (INTRODUCTION)}

Fenomena keracunan merupakan masalah yang serius pada komunitas pertanian di negara miskin dan berkembang. Keracunan penggunaan pupuk kimia dan pestisida merupakan suatu keadaan yang dapat terjadi akibat efek residu bahan kimia yang digunakan. Dampak kesehatan yang dialami juga dapat bersifat sistemik atau non-sistemik, secara akut ataupun kronis. Zat beracun di tanah tersebut dapat berdampak langsung kepada manusia ketika bersentuhan atau dapat mencemari melalui air tanah dan udara diatasnya (Sukmawati \& Maharani IP, 2004; Karyadi, 2008; Mahyuni, 2015; 
Charloq et.al. The farmer empowerment to reduce the chemical risk poisoning

Muslimah, 2015). Pengaruh residu pestisida dapat mengganggu kesehatan dengan berbagai gejala keracunan dan umumnya mengganggu metabolisme steroid, merusak fungsi tiroid, berpengaruh terhadap spermatogenesis, dan terganggunya sistem hormon endokrin (Endocrine Disrupting Pesticides) (Ipmawati, Setiani, \& Danudianti, 2016; Mahyuni, 2015; Munawir, 2010; Rumah Sakit Umum Kabanjahe, 2018; Rustia, Wispriyono, Susanna, \& Luthfiah, 2010; Sinulingga, 2006).

Pola hidup sehat yang akrab dengan lingkungan yang sehat telah menjadi trend baru meninggalkan pola hidup lama yang menggunakan bahan kimia non-alami, seperti pupuk, pestisida, dan hormon tumbuh sintetis dalam budidaya pertanian. Pola hidup sehat ini mensyaratkan jaminan bahwa produk pertanian harus beratribut aman dikonsumsi, kandungan nutrisi tinggi, dan ramah lingkungan. Pangan yang sehat dan bergizi tinggi dapat diproduksi dengan metode pertanian organik (Mayrowani, 2012). Pertanian organik merupakan metode pertanian yang menggunakan bahanbahan alam dan meninggalkan bahan kimia atau sintetis. Salah satu program yang dapat mendukung ke arah pertanian organik adalah pembuatan kolam organik. Kolam organik yang menghasilkan pupuk organik cair (POC) merupakan salah satu teknik yang digunakan untuk mengubah penggunaan bahan kimia sintesis dan pestisida yang berlebih (Syukur \& Melati, 2012).

Desa Sumber Mufakat Kecamatan Kabanjahe merupakan lokasi kegiatan pengabdian karena masyarakat petani masih menggunakan pupuk kimia dan pestisida sintetis yang cukup tinggi. Ketergantungan akan penggunaan bahan kimia sintetis ini membuat petani hanya mampu memasarkan produknya di pasar lokal dan tidak mengalami perkembangan yang berarti. Produk yang dihasilkan juga tidak menjamin keberlangsungan yang cukup berarti hingga dapat meningkatkan kesejahteraan petani. Petani mengakui kelemahan karena tidak dapat menghindari penggunaan pupuk kimia dan pestisida sintetis walaupun pada dasarnya petani memahami risiko keracunan namun hal tersebut diabaikan karena tuntutan kebutuhan hidup.

Tujuan kegiatan pengabdian secara umum adalah untuk menciptakan petani dan lingkungan yang sehat dengan produk yang aman dan bebas bahan kimia. Pemberdayaan petani melalui pemanfaatan kolam organik dengan menghasilkan POC diharapkan dapat mengubah perilaku penggunaan pestisida dan memperbaiki kondisi lingkungan pertanian.

\section{METODE PELAKSANAAN (METHODS)}

Tempat pengabdian pada masyarakat dilakukan di ladang partisipan yang dijadikan sebagai demplot pemanfaatan kolam organik. Untuk menjangkau manfaat yang lebih luas maka lokasi demplot disebar pada tiga ladang petani yaitu ladang partisipan mewakili dusun 4, dusun 9, dan dusun 1 di Desa Sumber Mufakat, Kecamatan Kabanjahe, Kabupaten Tanah Karo. Pengabdian dilaksanakan pada bulan Juni sampai November 2020.

Khalayak sasaran kegiatan pengabdian ini adalah masyarakat petani hortikultura di Desa Sumber Mufakat Kecamatan Kabanjahe Kabupaten Tanah Karo. Metode yang digunakan adalah demplot pembuatan kolam organik sebagai berikut:

\subsection{Bahan dan Alat}

Bahan yang digunakan dalam pengabdian ini adalah limbah organik yang diambil dari limbah alam tanaman yang terdapat di sekitar ladang petani. Adapun bahan-bahan yang digunakan sebagai bahan pembuatan POC adalah campuran tongkol-tongkol dan sisa jagung yang telah kering, hasil produk tanaman yang busuk-busuk atau tidak laku untuk dipasarkan seperti alpukat busuk, terong, daundaun pisang, kol, tomat busuk dan seluruh produk busuk dan tidak terpakai, tebu, kulit buah-buahan, cucian beras, sisa-sisa makanan, EM4 (Efektif Mikroogranisme), dan Molase. Untuk pembusukan bahan POC dilakukan proses fermentasi, kolam organik ditutup rapat dengan terpal plastik hitam selama minimal 14 hari atau maksimal 21 hari. Alat yang digunakan adalah $\mathrm{pH}$ Meter, plastik terpal, bambu, ember, plastik mulsa, tali, dan gayung berukuran (ml).

\subsection{Prosedur Kerja}


Charloq et.al. The farmer empowerment to reduce the chemical risk poisoning

Sasaran dari kegiatan ini adalah petani yang memiliki lahan sendiri dan bersedia menjadikan ladangnya sebagai demplot kolam organik yang dimanfaatkan sebagai media fermentasi Pupuk Organik Cair (POC). Aplikasi POC membutuhkan sasaran yang berkomitmen untuk beralih ke sistem pertanian organik sehingga mengurangi penggunaan pupuk kimia dan pestisida.

Kegiatan pengabdian kepada masyarakat petani khususnya pemanfaatan kolam organik dilakukan pada tiga kolam organik untuk dimanfaatkan pada tanaman cabai dan sayuran. Kegiatan pengabdian ini dilakukan dalam beberapa tahap kegiatan yaitu:

a. Identifikasi kondisi ladang yaitu tanah yang akan direncanakan memproduksi tanaman organik dengan memanfaatkan POC yang dibuat pada kolam organik.

b. Edukasi sistem pertanian organik sebagai satu program menekan risiko keracunan kimia.

c. Sosialisasi pemanfaatan kolam organik dan penetapan tanaman yang akan memanfaatkan POC selama program berjalan.

d. Mengobservasi pertumbuhan dan perkembangan tanaman diikuti pendampingan langsung.

e. Meningkatkan partisipasi masyarakat untuk memanfaatkan POC yang dihasilkan

\subsection{Indikator Keberhasilan.}

Indikator keberhasilan dari pengabdian ini adalah Pupuk Organik Cair (POC) yang masak dan dapat dimanfaatkan pada tanaman. Indikator lainnya adalah hasil produk yang memanfaatkan POC menunjukkan perubahan berupa tanah yang semakin subuh, daun semakin hijau, dan serangan hama penyakit yang berkurang.

\subsection{Metode Evaluasi}

Metode evaluasi dilakukan melalui pendampingan langsung secara intensif dari perkembangan pembuatan POC dan perkembangan tanaman yang memanfaatkan POC.

\section{HASIL DAN PEMBAHASAN (RESULT AND DISCUSSION)}

\subsection{Identifikasi Kondisi Tanah Ladang Petani}

Kegiatan pengabdian masyarakat yang dilakukan di Desa Sumber Mufakat diawali dengan melakukan identifikasi terhadap kondisi tanah dari ladang petani yang menjadi sasaran kegiatan PPM. Hasil identifikasi dari 20 ladang petani termasuk dalam kategori kurang baik. Hal ini disebabkan karena tingginya frekuensi penggunaan pupuk kimia dan pestisida yang digunakan. Penggunaan pupuk kimia dan pestisida juga dilakukan secara bebas menurut kebiasaan tanpa mengikuti prosedur yang ditetapkan. Dosis pestisida diberikan dengan penakaran jumlah campuran menurut kebiasaan dan pengalaman petani sehingga berpotensi besar meningkatkan residu racun di tanah yang cukup signifikan. Tingginya frekuensi dan dosis penggunaan bahan kimia seperti pestisida dan pupuk sintetis berpengaruh terhadap kesehatan petani seperti menurunnya kadar enzim kholinesterase, gangguan keseimbangan, anemia, goiter, dan keluhan kesehatan lainnya bahkan peningkatan residu kimia di lingkungan. Perilaku ini harus diubah untuk mengurangi risiko keracunan yang berpotensi sangat besar terjadi pada petani yang tidak patuh terhadap aturan penggunaan dan merugikan bagi tanah yang terus-menerus terpajan dengan bahan kimia (Karyadi, 2008; Kurniadi \& Maywita, 2018; Mahyuni, 2015; Okvitasari, Anwar, \& Suparmin, 2017; Pawitra, 2012; Prasetya, Wibawa, \& Enggarwati, 2018; Samosir, Setiani, \& Nurjazuli, 2017).

Hasil identifikasi menggambarkan bahwa kondisi tanah petani termasuk dalam masa konservasi stadium 2 dan 3 bila diupayakan untuk beralih ke pertanian organik. Beberapa penyebab yang menimbulkan keadaan ini diantaranya pemberian pestisida yang over dose, penggunaan herbisida untuk membasmi rumput atau gulma sebelum melakukan penanaman, kebiasaan membakar rerumputan di ladang, pemupukan yang berlebihan, dan penggunaan pestisida yang beragam dan berlebihan. Hal ini menyebabkan kondisi tanah menjadi miskin akan unsur hara dan bepengaruh terhadap hasil produksi tanaman. Penggunaan pupuk dan pestisida berlebihan dapat mempengaruhi produktivitas ke depan. Beberapa hasil penelitian, penggunaan pupuk dan beberapa jenis pestisida mengakibatkan tanah dapat mengandung logam berat, plumbum, kandungan aldrin, dan dealdrin yang perlu diwaspadai (Karyadi, 2008; Mahyuni, 2020; Narwanti, Sugiharto, \& Anwar, 2013). 


\subsection{Pembuatan Kolam Organik dan Pupuk Organik Cair}

Permasalahan dari kondisi tanah pada ladang petani ini diatasi melalui program PPM berupa pembuatan Pupuk Organik Cair (POC) dengan teknologi tepat guna yaitu kolam organik yang ukurannya didesain sesuai luas lahan yang dikelola petani. Tujuan pembuatan kolam organik sebagai media pembuatan POC dapat dimanfaatkan untuk memperbaiki kondisi tanah dan tanaman petani sekitarnya. Target sasaran POC juga untuk mengubah kebiasaan petani menggunakan bahan kimia sintetis yang berlebih dan mendukung petani untuk beralih ke pertanian organik. Kegiatan pembuatan kolam organik ditempatkan pada ladang petani yang berkomitmen untuk bertani organik. Pada kegiatan PPM ini kolam organik dibuat pada tiga ladang partisipan yang tersebar di area Desa Sumber Mufakat yaitu ladang partisipan 1 di dusun 1, ladang parstisipan 2 di dusun 4, dan ladang partisipan 3 di dusun 9 sehingga pemanfaatan POC menjadi lebih luas. Ukuran kolam organik yang dimanfaatkan pada tiga ladang di Desa Sumber Mufakat masing-masing adalah $5 \mathrm{~m}$ x 3 m dengan kedalaman $90 \mathrm{~cm}$. POC yang dibuat pada kolam organik sangat berfungsi untuk memperbaiki kondisi tanah dan membantu petani menjadi lebih siap untuk beralih ke pertanian organik. Disamping itu, petani juga semakin berdaya dan mulai mengurangi penggunaan pestisida yang membutuhkan biaya mahal. Pembuatan pupuk organik cair (POC) sebagai produk yang dimanfaatkan melalui media kolam organik ini sangatlah mudah dan memenuhi konsep ekologi lingkungan. Pemakaian pupuk organik cair ini salah satu Teknologi Tepat Guna (TTG), meningkatkan efisiensi dan efektifitas pada pertumbuhan dan produksi tanaman.

Pemberdayaan ke arah organik tidak hanya meniadakan penggunaan kimia sintesis namun juga memanfaatkan sumber daya yang ada sehingga tidak dapat dipisahkan dari dimensi ekonomi, sosial, dan lingkungan. Pertanian organik dapat meningkatkan perekonomian petani karena murah dan ramah lingkungan. Secara sosial kesadaran petani untuk berubah dan meninggalkan penggunaan bahan kimia dapat menyeimbangkan ekologi lingkungan bahkan menghasilkan produk yang sehat dan bebas dari bahan kimia (Astuti \& Widyastuti, 2016; Mayrowani, 2012; Syukur \& Melati, 2012).

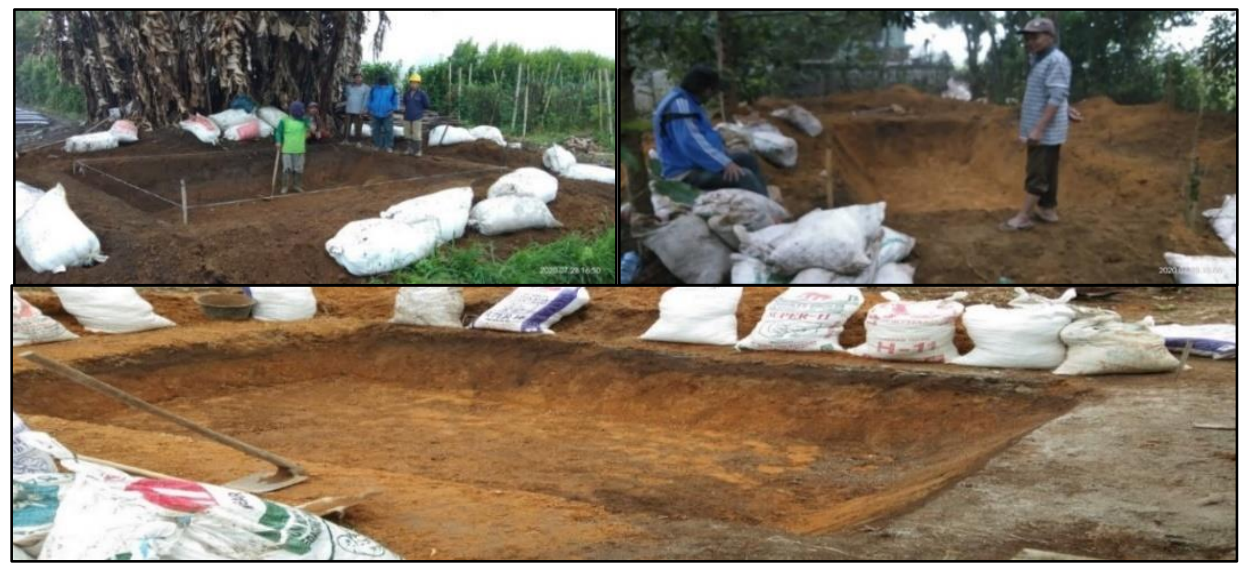

Gambar 3.1 Pembuatan Kolam Organik pada Tiga Ladang Partisipan

\subsection{Edukasi Pertanian Organik melalui Pemanfaatan POC}

Kegiatan pembuatan kolam organik disertai dengan kegiatan mengedukasi masyarakat petani akan manfaat POC yang dibuat di kolam organik. Edukasi dihadiri petani dan dilakukan di salah satu ladang partisipan tepatnya dusun 9 sebagai demplot pemanfaatan POC pada tanggal 29 Juli 2020. Edukasi disajikan secara sederhana dengan menerangkan manfaat kolam organik sebagai POC yang dapat membantu memperbaiki kondisi tanah hingga kembali subur dan sehat. POC sangat bermanfaat dalam mengurangi risiko bahaya kimia yang dapat mempengaruhi lingkungan, kesehatan petani, dan produk yang sehat.

Perhatian dan antusiasme petani tersalurkan saat edukasi terutama terkait bahan-bahan yang dibutuhkan dalam pembuatan POC yang merupakan isi dari kolam organik. Bahan tersebut diambil 
dari limbah alam tanaman yang terdapat di sekitar ladang petani (limbah organik). Limbah organik dimanfaatkan kembali karena pada dasarnya prinsip pembuatan POC menggunakan teknologi komposting. Pengelolaan limbah organik ini juga dapat mengurangi sampah yang umumnya merupakan sumber penyakit. Bahkan POC dapat berperan lebih baik daripada pupuk kandang karena banyak mengandung unsur N dan K yang tinggi (Marliah, Hayati, \& Muliansyah, 2012; Merawati \& Frismayudha, 2018; Purnawati, Bagyono, \& Fauzie, 2016; Suhastyo, 2019).

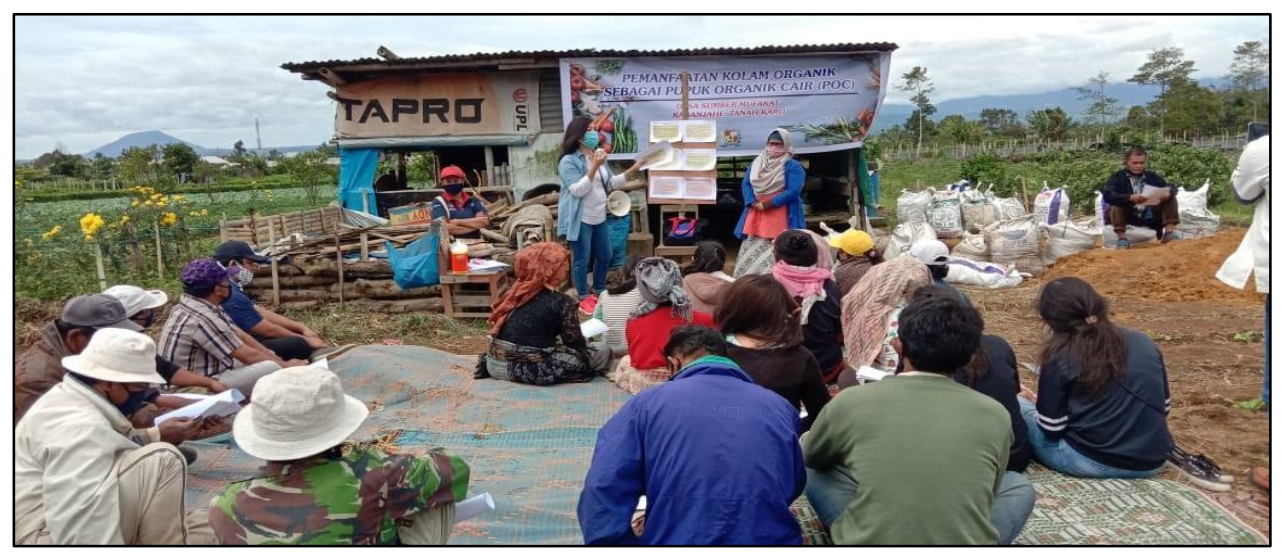

Gambar 3.2 Edukasi Sistem Pertanian Organik

\subsection{POC dan Pemanfaatannya}

Setelah melewati masa fermentasi selama 21 hari maka penutup kolam akan dibuka untuk melihat POC yang dihasilkan dan dilakukan secara bertahap pada ketiga ladang. Ladang 1 dan 2 dibuka pada tanggal 19 Agustus 2020 sedangkan ladang 3 dibuka pada tanggal 24 Agustus 2020. Dari hasil fermentasi selama 21 hari dari ketiga ladang 3 memiliki POC yang sudah matang dengan indikator tidak berbau, kekentalan yang bagus, dan warna kecoklatan. Aplikasi POC pada tanaman dilakukan dengan pengenceran bervariasi 1:10, 10:40 atau 1:100, tergantung kondisi kerusakan tanah dan permintaan tanaman yang ada disekitarnya. Apabila kondisi $\mathrm{pH}$ tanah lebih asam, maka frekuensi penyiraman lebih banyak dan dosis atau konsentrasi POC lebih kental. Hal ini tidak berbahaya seperti penggunaan dosis pestisida atau pupuk kimia pada umumnya karena pupuk organik cair ini tidak memberikan residu atau racun dalam tanah dan tanaman.

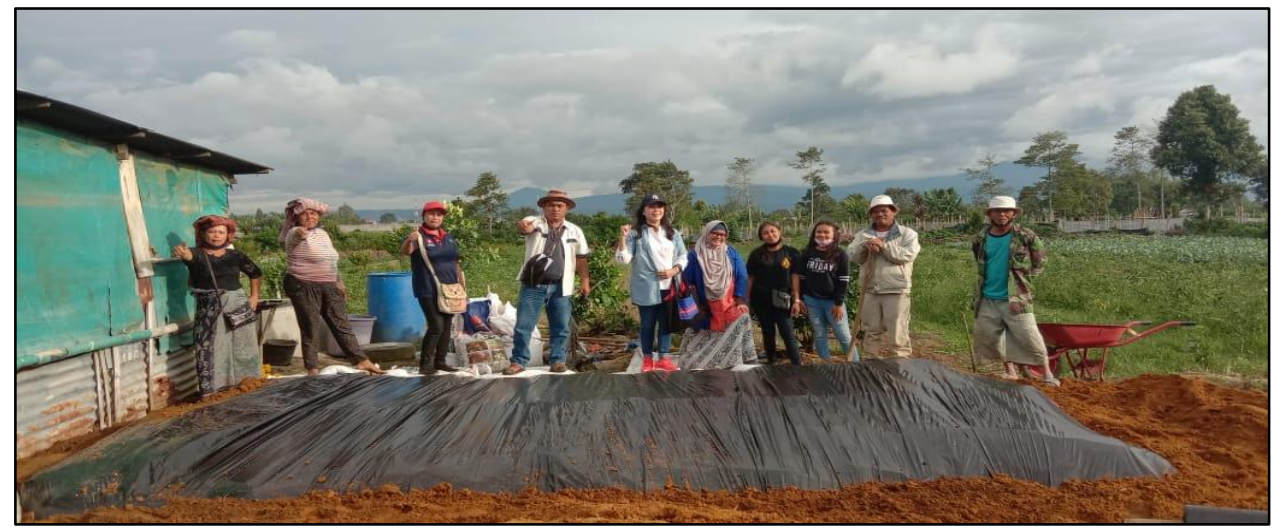

Gambar 3.3 Fermentasi POC pada Kolam Organik

Setelah kolam organik dibuka dan POC yang berhasil difermentasikan dapat dimanfaatkan, maka tim PPM melakukan pendampingan secara intens kepada petani selama masa pemanfaatan POC. Pendampingan tidak hanya dilakukan secara offline melalui peninjauan dan observasi langsung namun juga dilakukan secara online melalui komunikasi via telepon dan media sosial yaitu Whatsapp Group. Selama pendampingan, petani banyak menerima informasi dan ilmu baru dan 
Charloq et.al. The farmer empowerment to reduce the chemical risk poisoning

menyadari bahwa selama ini telah menyia-nyiakan waktu dan kesempatan untuk mengurangi penggunaan bahan kimia dan pestisida yang dapat berbahaya bagi kesehatan petani.

POC yang dibuat pada media kolam oragnik mengandung protein komplek, enzim, vitamin, hormon, pupuk NPK, $\mathrm{Mg}, \mathrm{Fe}, \mathrm{Cu}, \mathrm{Zn}$, dan mikroorganisme yang menguntungkan untuk tanah dan tanaman. POC ini tidak mengandung risiko racun sehingga penggunaannya tidak berpatokan kepada takaran namun menekankan pada frekuensi pemakaian, semakin sering digunakan kondisi tanah dan tanaman akan semakin baik. Dengan pemanfaatan POC ini kadar tanah yang sudah sakit kembali normal dengan memiliki kesuburan tanah yang menghasilkan produksi tanaman yang meningkat dan sehat. Program ini berhasil meningkatkan produksi tanaman petani di Desa Sumber Mufakat Kecamatan Kabanjahe yang ditunjukkan dengan perubahan pada kondisi tanah dan tanaman berupa tanah yang semakin subur, meningkatnya tebal daun dan menjadi lebih hijau, batang tanaman lebih kokoh, serta serangan hama, dan penyakit dapat ditekan.

Pemberdayaan masyarakat dalam menekan risiko keracunan akibat penggunaan bahan kimia seperti pupuk sintetis dan pestisida dapat diatasi dengan perubahan menuju pertanian organik. Kolam organik merupakan teknologi tepat guna yang dijadikan sebagai media pembuatan Pupuk Organik Cair (POC) yang bermanfaat bagi petani. POC merupakan pupuk yang dibuat berbahan dasar alam dan dikembalikan ke alam. POC sangat bermanfaat untuk membenahi kondisi tanah yang rudak alkibat penggunaan bahan kimia yang berlebihan dan kronis.

Kegiatan ini menunjukkan keberhasilan yang memuaskan bagi petani. POC yang dibuat pada kolam organik bersama sama masyarakat berhasil sempurna sesuai dengan waktu fermentasi yang ditargetnya sehingga POC dapat dimanfaatkan oleh petani. Pemanfaatan POC oleh masyarakat juga menunjukkan keberhasilan pada kondisi tanah dan tanaman yang diproduksi. Tanah yang menggunakan POC menjadi semakin subur dan gembur. Tanaman yang diproduksi juga menunjukkan perubahan yang lebih baik yang ditunjukkan dengan meningkatnya tebal daun dan daun menjadi lebih hijau, batang tanaman lebih kokoh, serta berkurangnya serangan hama dan penyakit busuk daun pada tanaman. Keberhasilan dari pemanfaatan POC ini menjadi motivasi dan stimulus bagi petani untuk mulai meninggalkan penggunaan bahan kimia dan beralih ke pertanian organik.

\section{KESIMPULAN (CONCLUSION)}

Berdasarkan hasil kegiatan pengabdian yang dilakukan melalui program pemanfaatan POC melalui kolam organik dapat disimpulkan bahwa POC yang diproduksi memberi manfaat bagi masyarakat disamping memperbaiki kondisi tanah juga meningkatkan kualitas produksi yang lebih bersifat alami (organik).

\section{UCAPAN TERIMAKASIH (ACKNOWLEDGMENTS)}

Penulis ucapkan kepada Kemenristek/BRIN yang telah mendukung pendanaan demi terlaksananya kegiatan pengabdian ini dengan nomor kontrak 285/UN5.2.3.2.1/PPM/2020. Terima kasih juga kami ucapkan kepada Bapak Kepala Desa Sumber Mufakat Kecamatan Kabanjahe Kabupaten Karo. Partisipasi yang sangat berharga dari petani yang telah sukarela menjadi ladang percontohan demplot kolam organik Bapak Timur Tarigan, Bapak Irwanto Karo Karo, dan Bapak Tulus Sitepu serta seluruh masyarakat Desa Sumber Mufakat yang telah berkontribusi dalam mensukseskan kegiatan pengabdian ini.

\section{DAFTAR PUSTAKA (REFERENCES)}

Astuti, W., \& Widyastuti, C. R. (2016). Pestisida Organik Ramah Lingkungan Pembasmi Hama Tanaman Sayur. Rekayasa, 14(2), 115-120.

Ipmawati, P. A., Setiani, O., \& Danudianti, Y. H. (2016). Analisis Faktor-Faktor Risiko yang Mempengaruhi Tingkat Keracunan Pestisida pada Petani di Desa Jati, Kecamatan Sawangan, 
Charloq et.al. The farmer empowerment to reduce the chemical risk poisoning

Kabupaten Magelang, Jawa Tengah. Kesehatan Masyarakat, 4(1), 427-435.

Karyadi, K. (2008). Dampak Penggunaan Pupuk dan Pestisida yang Berlebihan terhadap Kandungan Residu Tanah pertanian Bawang Merah di Kecamatan Gemun Kabupaten Kendal. Agromedia, 26(1), 10-19.

Kurniadi, D., \& Maywita, E. (2018). Faktor-Faktor yang Berhubungan dengan Keluhan Kesehatan Akibat Paparan Pestisida pada Petani Hortikultura di Dessa Siulak Deras Mudik Kabupaten Kerinci. Jurnal Menara Ilmu, 12(80), 13-18.

Mahyuni, E. L. (2015). Faktor Risiko dalam Penggunaan Pestisida terhadap Keluhan Kesehatan pada Petani di Kecamatan Berastagi Kabupaten Karo 2014. Jurnal Kesmas, 9(1), 79-89.

Mahyuni, E. L. (2020). Pemberdayaan Masyarakat Petani Hortikultura dalam Mencegah Risiko Keracunan Pestisida di Kecamatan Kabanjahe Kabupaten Karo (Disertasi, Universitas Sumatera Utara.

Marliah, A., Hayati, M., \& Muliansyah, I. (2012). Pemanfaatan Pupuk Organik Cair terhadap Pertumbuhan dan Hasil Beberapa Varietas Tomat (Lycopersicum Esculentum L.). Jurnal Agrista, $16(3), 122-128$.

Mayrowani, H. (2012). Pengembangan Pertanian Organik di Indonesia (The Development of Organic Agriculture in Indonesia). Forum Penelitian Agro Ekonomi, 30(2), 91-108.

Merawati, F., \& Frismayudha, E. (2018). Pupuk Organik Cair sebagai Pemberdayaan Sampah Organik di Dusun Banjar. Jurnal Pemberdayaan: Publikasi Hasil Pengabdian Kepada Masyarakat, 2(2), 365-368. https://doi.org/10.12928/jp.v2i2.513

Munawir, K. (2010). Pestisida Organoklorin di Perairan Teluk Klabat-Pulau Bangka. Oseanologi dan Limnologi Di Indonesia, 36(1), 1-19.

Narwanti, I., Sugiharto, E., \& Anwar, C. (2013). Residu Pestisida Aldrin dan Dieldrin pada Sampel Tanah dan Air di Desa Srigading Kecamatan Sanden Kabupaten Bantul. Pharmaciana, 3(2), 23 28. https://doi.org/10.12928/pharmaciana.v3i2.427

Okvitasari, R., Anwar, C., \& Suparmin. (2017). Hubungan antara Keracunan Pestisida dengan Kejadian Anemia pada Petani Kentang di Gabungan Kelompok Tani Al-Farruq Desa Patak Banteng Kecamatan Kejajar Kabupaten Wonosobo Tahun 2016. Buletin Kesehatan Lingkungan Masyarakat, 36(3), 299-310. https://doi.org/10.31983/keslingmas.v36i3.3109

Pawitra, A. S. (2012). Pemakaian Pestisida Kimia Terhadap Kadar Enzim Cholinesterase dan Residu Pestisida dalam Tanah. Jurnal Ilmiah Kesehatan Media Husada, 1(1), 19-30. https://doi.org/10.33475/jikmh.v1i1.59

Prasetya, E., Wibawa, A. A., \& Enggarwati, E. (2018). Hubungan Faktor-Faktor Paparan Pestisida Terhadap Kadar Cholinesterase pada Petani Penyemprot Tembakau di Desa Karangjati Kabupaten Ngawi. Jurnal Penelitian Kesehatan Masyarakat, 1(1).

Purnawati, S., Bagyono, T., \& Fauzie, M. M. (2016). Pemanfaatan Sampah Buah, Air Cucian Beras, dan Kotoran Ayam sebagai Pupuk Organik Cair. Sanitasi: Jurnal Kesehatan Lingkungan, 7(4), 193198.

Rumah Sakit Umum Kabanjahe. (2018). Data Pasien Intoksikasi Periode Januari-Oktober 2017: Rekam Medik Rumah Sakit Umum Kabanjahe Kabupaten Karo. Kabanjahe.

Rustia, H. N., Wispriyono, B., Susanna, D., \& Luthfiah, F. N. (2010). Lama Pajanan Organofosfat terhadap Penurunan Aktivitas Enzim Kholinesterase dalam Darah Petani Sayuran. Makara Kesehatan, 14(2), 95-101.

Samosir, K., Setiani, O., \& Nurjazuli, N. (2017). Hubungan Pajanan Pestisida dengan Gangguan Keseimbangan Tubuh Petani Hortikultura di Kecamatan Ngablak Kabupaten Magelang. Jurnal Kesehatan Lingkungan Indonesia, 16(2), 63-69. https://doi.org/10.14710/jkli.16.2.63-69

Sinulingga, K. (2006). Telaah Residu Organoklor pada Wortel (Dacus carota L.) di Kawasan Sentra Kab. Karo Sumut. Jurnal Sistem Teknik Industri, 7(1), 92-97.

Suhastyo, A. A. (2019). Pemberdayaan Kelompok Wanita Tani Melalui Pelatihan Pembuatan Pupuk Organik Cair. Jurnal Penelitian Dan Pengabdian Kepada Masyarakat UNSIQ, 6(2), 60-64. https://doi.org/10.32699/ppkm.v6i2.580

Syukur, M., \& Melati, D. M. (2012). Pengembangan Sayuran Organik. Pengembangan Pertanian 
Charloq et.al. The farmer empowerment to reduce the chemical risk poisoning

Organik Di Indonesia, 175-192. 